Original Paper

\title{
Penggunaan Media Gambar untuk Meningkatkan Hasil Belajar Matematika Siswa
}

\author{
Sulastri Pebri Utami ${ }^{1 *}$ \\ ${ }^{1}$ Sekolah Dasar Negeri 1 Midang, Gunungsari, Indonesia.
}

*Corresponding Author: Sulastri Pebri Utami, Sekolah Dasar Negeri 1 Midang, Gunungsari, Indonesia; Email:

sulastriutami@gmail.com

\begin{abstract}
Abstrak: Tujuan penelitian ini adalah untuk meningkatkan hasil belajar matematika dengan menggunakan media gambar siswa kelas III SDN 1 Midang tahun pelajaran 2014/2015. Jenis Penelitian ini adalah penelitian tindakan kelas (classroom action research) atau disingkat PTK. Penelitian Tindakan Kelas Meliputi empat tahapan yaitu perencanaan tindakan, pelaksanaan tindakan, pengamatan tindakan, dan refleksi. Subyek penelitian ini adalah siswa kelas III Semester 2 Tahun Pelajaran 2014/2015. Subjek penelitian ini berjumlah 29 siswa yang terdiri dari 12 laki-laki dan 17 perempuan. Berdasarkan hasil penelitian ini, dapat ditarik kesimpulan bahwa: 1) Penggunaan media gambar dapat meningkatkan hasi belajar matematika siswa kelas III SDN 1 Midang tahun pelajaran 2014/2015 yang ditunjukkan oleh nilai rata-rata hasil belajar siswa dari siklus I sebesar 70 menjadi 78.93 pada ke siklus II. Demikian juga dengan ketuntasan klasikal matematika siswa dari 78,5\% menjadi 82,14\% sehingga penelitian sudah dapat dikatakan berhasil karena telah mencapai ketuntasan yang diharapkan. 2) Penggunaan media gambar dapat meningkatkan keaktifan siswa dalam proses belajar mengajar. Peningkatan tersebut ditunjukkan oleh rata-rata aktivitas siswa yang sebelumnya $75 \%$ dengan katagori aktif menjadi $87,5 \%$ dengan katagori sangat aktif.
\end{abstract}

Kata kunci: Media Gambar; Hasil Belajar; Matematika.

\section{Pendahuluan}

Pendidikan nasional berfungsi menge Matematika merupakan salah satu materi pelajaran yang disampaikan oleh guru sejak jenjang paling dasar pada Sekolah Dasar yaitu dimulai dari kelas I. Matematika mempunyai peranan penting dalam perkembangan Ilmu Pengetahuan dan Teknologi (IPTEK). Matematika juga dapat menumbuhkan siswa berpikir kritis, logis, rasional, dan percaya diri, sehingga matematika harus dapat dipahami oleh setiap siswa. Selain itu, penguasaan Matematika SD merupakan kemampuan jenjang awal yang harus dimiliki oleh siswa sehingga dapat memudahkannya untuk melanjutkan ke jenjang pendidikan berikutnya.

Perkembangan Ilmu Pengetahuan dan Teknologi yang pesat dewasa ini berpengaruh disegala bidang pendidikan terutama pada mata pelajaran Matematika khususnya lagi berhitung/aritmatika. Aritmatika/berhitung adalah bidang yang berkenaan dengan sifat hubungan bilangan- bilangan nyata dengan perhitungan terutama menyangkut penjumlahan, pengurangan, perkalian dan pembagian (Mulyono, 2003)

Perkembangan pengajaran matematika di sekolah sangat dipengaruhi oleh banyak factor yang sangat berkaitan. Faktor- faktor tersebut antara lain faktor siswa, guru dan materi pelajran itu sendiri. Salah satu factor yang cukup berperan adalah materi pelajaran, karena selain berkaitan dengan kesesuaian dan kesiapan siswa, materi pelajaran juga harus memperhatikan materi-materi sebelumnya sebagai prasyarat unuk mempelajari materi berikutnya (Rahmawati, 2014).

Pembelajaran matematika adalah proses yang kompleks dan mengandung banyak variabel dan semua variabel saling berhubungan, kemudian matematika di SD adalah matematika dengan pengertian materi dan pola pikirnya telah dipilih dan disesuaikan proses kemampuan siswa walaupun obyek matematika adalah abstrak tetapi 
dalam pengajarannya dapat dimulai dari obyek yang kongkrit (Hidayat, 2001). Oleh karena itu, guru harus berupaya maksimal dalam mendidik siswanya dan dapat meningkatkan minat siswa dalam pembelajaran matematika, serta memberikan kesempatan kerja kepada siswa untuk belajar mandiri.

Namun demikian, pada kenyataannya pelajaran matematika tetap menjadi mata pelajaran yang dianggap sulit dan tidak menyenangkan. Berdasarkan hasil observasi di Kelas III SDN 1 Midang Tahun 2014, dari 29 orang siswa, hanya terdapat 8 orang siswa yang memperoleh nilai tinggi dengan nilai rata-rata ulangan hariannya 67,4 dan itupun masih di bawah KKM yaitu 70 . Permasalahan ini terjadi karena ketergantungan siswa terhadap guru dengan menggunakan metode pembelajaran yang konvensional sehingga membuat proses pembelajaran menjadi membosankan, monoton dan kurang kreatif.

Berdasarkan permasalahan di atas, diperlukan metode pembelajaran yang lebih menekankan pada aktivitas dan kreatifitas belajar siswa selama proses pembelajaran berlangsung supaya bias mengoptimalkan kemampuan siswa. Keterlibatan siswa dalam pembelajaran harus lebih banyak dibanding dengan guru. Salah satu model pembelajaran yang bias diterapkan untuk mengatasi permasalahan di atas adalah dengan menggunakan media gambar. Dengan media gambar siswa akan lebih aktif untuk belajar dan memperjelas hubungan antara isi materi pembelajaran dengan dunia nyata, lebih konsentrasi untuk melihat dan mendengarkan guru saat pembelajaran berlangsung. Penyajian obyek dalam bentuk gambar dapat disajikan melalui bentuk nyata maupun kreasi khayalan belaka sesuai dengan bentuk yang pernah dilihat oleh orang yang menggambarnya (Sudjana, 2007).

Dengan demikian, peneliti melakukan penelitian ini dengan judul: Penggunaan Media Gambar untuk Meningkatkan Hasil Belajar Matematika Siswa Kelas III SDN 1 Midang Tahun Pelajaran 2014/2015 dengan tujuan untuk meningkatkan hasil belajar matematika dengan menggunakan media gambar siswa kelas III SDN 1 Midang tahun pelajaran 2014/2015. Hasil dari penelitian tindakan kelas ini diharapkan dapat memberikan manfaat seperti: 1) Bagi guru agar dapat menggunakan media gambar untuk meningkatkan hasil belajar matematika. 2) Bagi siswa agar dapat membangkitkan minat dan motivasi dalam belajar matematika. 3) Bagi sekolah agar sekolah dapat menjadikan media gambar sebagai alternative dalam meningkatkan hasil belajar, tidak hanya pada mata pelajaran matematika saja tetapi juga pada setiap mata pelajaran yang memungkinkan untuk menggunakan media gambar.

\section{Metode}

Jenis Penelitian ini adalah penelitian tindakan kelas (classroom action research) atau disingkat PTK. Penelitian Tindakan Kelas Meliputi empat tahapan yaitu perencanaan tindakan, pelaksanaan tindakan, pengamatan tindakan, dan refleksi. Setiap siklus dilaksanakan sesuai dengan skenario yang telah dibuat dan memuat empat tahap kegiatan, yaitu tahap perencanaan tindakan, tahap pelaksanaan tindakan, tahap observasi, dan tahap evaluasi dan refleksi (Wardhani, 2008). Adapun tahap-tahap penelitian yang dilakukan dapat dilihat pada Gambar 1 berikut.

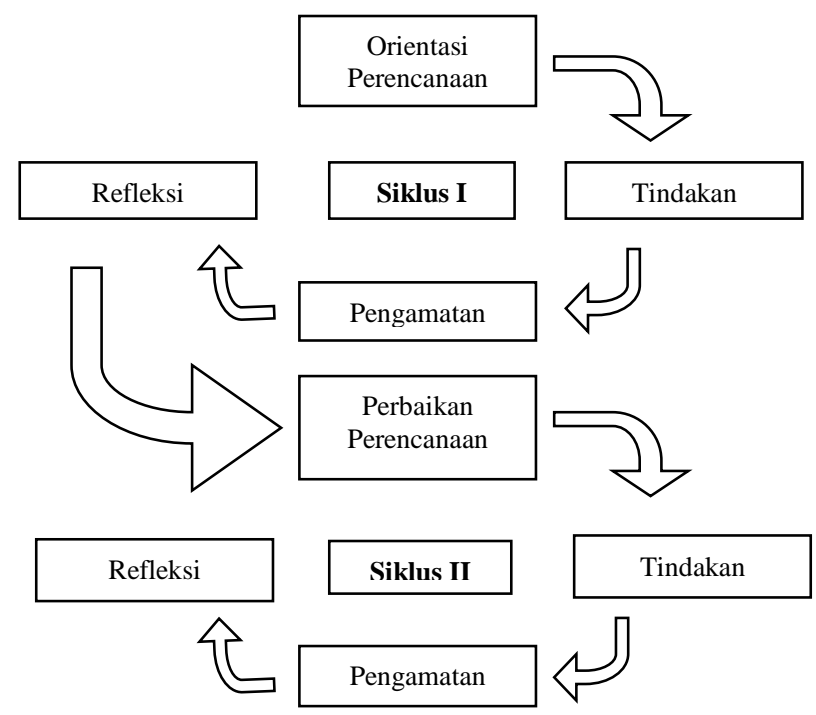

Gambar 1: Model Penelitian Tindakan Kelas Arikunto, (2010).

Penelitian ini akan dilaksanakan di SDN 1 Midang, Kecamatan Gunungsari, Kabupaten Lombok Barat pada Semester Genap mulai dari bulan Januari s.d. Maret 2015. Subyek penelitian ini adalah siswa kelas III Semester 2 Tahun Pelajaran 2014/2015. Subjek penelitian ini 
berjumlah 29 siswa yang terdiri dari 12 laki-laki dan 17 perempuan.

\section{Hasil dan Pembahasan}

Kegiatan pembelajaran pada masing-masing siklus dilaksanakan dalam satu kali pertemuan dan dilaksanakan selama 3 x 35 menit. Pertemuan pada siklus I dilaksanakan pada hari Kamis 26 Maret 2015 untuk siklus I dan tanggal 12 Maret 2015 untuk siklus II. Selama proses pembelajaran pada siklus I berlangsung, seluruh aktivitas guru dan Tabel 1. Data Hasil Observasi Aktivitas Siswa Siklus I siswa diamati secara langsung oleh observer. Hasil pengamatan tersebut ditulis secara langsung dalam lembar observasi aktivitas guru dan siswa yang sebelumnya telah dipersiapkan oleh peneliti. Adapun untuk mengetahui hasil belajar matematika siswa diperoleh melalui hasil evaluasi yang diberikan pada tiap akhir siklus.

Hasil Observasi aktivitas siswa bertujuan untuk mengetahui sejauh mana kegiatan siswa dalam mengikuti kegiatan pembelajaran. Adapun hasil observasi untuk aktivitas siswa dalam siklus I dapat dilihat dari Tabel 1.

\begin{tabular}{llll}
\hline No & Indikator & Skor Siklus I & Skor Siklus II \\
\hline 1 & Antusiasme siswa dalam mengikuti pelajaran. & 11 & 12 \\
2 & Antusiasme siswa terhadap media pembelajaran yang digunakan & 9 & 10 \\
& guru. & 8 & 9 \\
3 & Interaksi siswa dengan guru. & 9 & 10 \\
4 & Interaksi siswa dengan siswa & 8 & 10 \\
5 & Presentasi hasil kerja kelompok. & 9 & 12 \\
6 & Partisipasi siswa dalam menutup pembelajaran. & 54 & 63 \\
& Jumlah Skor & $75 \%$ & $87,5 \%$ \\
& Presentase Keberhasilan & Aktif & Sangat aktif \\
\hline
\end{tabular}

Berdasarkan Tabel 1, aktivitas siswa selama proses pembelajaran berlangsung pada siklus I mencapai $75 \%$ dengan katagori aktif. Hasil observasi pada aktvitas siswa pada siklus I tergolong baik, namun penelitian perlu dilanjutkan ke siklus II sebab hasil ini belum mencapai kriteria ketuntasan aktivitas siswa. Hasil presentase keaktifan siswa dalam kegiatan pembelajaran pada siklus II mengalami peningkatan dari $75 \%$ pada siklus I dengan katagori aktif menjadi $87,5 \%$ pada siklus II dengan katagori sangat aktif. Nilai ini Tabel 2. Data Hasil Observasi Aktivitas Guru Siklus I mengalami peningkatan sebesar $12,5 \%$. Dengan demikian, aktivitas siswa dari siklus I mengalami peningkatan di siklus II. Aktivitas guru pada siklus II menunjukkan adanya peningkatan yaitu $85,71 \%$ dengan katagori sangat baik.

Hasil observasi guru ini bertujuan untuk melihat apakah dalam melakukan pembelajaran kegiatan guru sudah berjalan dengan baik atau tidak. Adapun data hasil observasi aktivitas guru pada siklus I ini dapat dilihat dari Tabel 2.

\begin{tabular}{llll}
\hline No & Indikator & Skor Siklus I & Skor Siklus II \\
\hline 1 & Membangkitkan minat dan motivasi dalam belajar & 4 & 4 \\
2 & Pemberian apersepsi kepada siswa & 3 & 4 \\
3 & Penyampaian materi menggunakan media gambar & 3 & 4 \\
4 & Melibatkan siswa dalam proses pembelajaran & 3 & 3 \\
5 & Membimbing siswa dalam kegiatan belajar (kerja kelompok). & 3 & 4 \\
6 & Menyimpulkan hasil kerja kelompok dan penugasan & 3 & 3 \\
7 & Mengakhiri pelajaran & 3 & 3 \\
& Jumlah Skor & 22 & 24 \\
& Presentase Keberhasilan & $78,57 \%$ & $85,71 \%$ \\
& Kriteria Aktivitas & baik & Sangat baik \\
\hline
\end{tabular}

Berdasarkan Tabel 2. aktivitas guru selama proses pembelajaran berlangsung pada siklus I mencapai 78,57 \% dengan katagori baik. Hasil observasi pada aktvitas guru pada siklus I tergolong baik, namun penelitian perlu dilanjutkan ke siklus II sebab hasil ini belum mencapai kriteria 
ketuntasan aktivitas guru. Presentase aktivitas guru mengalami peningkatan sebesar 7,14\%. Hasil evaluasi pada siklus II menunjukkan ketuntasan belajar siswa secara klasikal mengenai sifat-sifat bangun datar mencapai $82,76 \%$ dengan katagorikan sangat baik. Sehingga penilaian telah memenuhi kriteria ketuntasan klasikal yang telah ditentukan yaitu $80 \%$ siswa memenuhi KKM.

Adapun ringkasan dari hasil penelitian siklus I dan siklus II yang memuat aktivritas siswa, aktivitas guru, nilai rata-rata siswa secara klasikal dan ketuntasan belajar siswa dapat dilihat pada tabel di bawah ini:

Tabel 3. Perbandingan Hasil Observasi Dan Evaluasi siklus I dan Siklus II

\begin{tabular}{lllllll}
\hline \multirow{2}{*}{ Siklus } & \multirow{2}{*}{$\begin{array}{l}\text { Nilai Rata-Rata } \\
\text { Hasil Belajar }\end{array}$} & \multirow{2}{*}{$\begin{array}{l}\text { Ketuntasan } \\
\text { Klasikal }\end{array}$} & $\begin{array}{l}\text { Aktivitas Siswa } \\
\text { Rata-Rata }\end{array}$ & $\begin{array}{l}\text { Kriteria } \\
\text { Aktivitas }\end{array}$ & $\begin{array}{l}\text { Presentase } \\
\text { Rata-Rata }\end{array}$ & $\begin{array}{l}\text { Kriteria } \\
\text { Aktivitas }\end{array}$ \\
\hline I & 70 & $78,57 \%$ & $75 \%$ & Aktif & $78,57 \%$ & Baik \\
II & 79,31 & $82.76 \%$ & $87,5 \%$ & Sangat Aktif & $85,71 \%$ & Sangat Baik \\
\hline
\end{tabular}

Dengan mengamati Tabel 3, dapat dilihat bahwa pada siklus I aktivitas guru dan siswa belum memenuhi kriteria ketuntasan aktivitas yang telah ditentukan dalam penelitian ini, begitu juga dengan ketuntasan klasikal untuk hasil belajar matematika dengan penggunaan media gambar masih dibawah $80 \%$. Walaupun demikian, secara umum penggunaan media gambar dalam hasil belajar matematika berjalan cukup baik, Sehingga dilakukan perbaikan pada indikator-indikator pembelajaran siklus I yang belum maksimal pada siklus II.

Hasil evaluasi siswa pada siklus I, terdapat 22 orang $(78,57 \%)$ siswa sudah memenuhi target dan 6 orang masih belum memenuhi target yaitu KKM 70. Berdasarkan hasil evaluasi, nilai tertinngi yang diperoleh pada siklus I yaitu 90 sebanyak 3 orang dan nilai terendah 30 sebanyak 1 orang dengan nilai rata-rata kelas 70 . Hasil evaluasi pada siklus I menunjukkan bahwa ketuntasan belajar siswa secara klasikal mengenai sifat-sifat bangun datar mencapai 78,57\% dikategorikan baik. Akan tetapi hasil yang dicapai ini belum memenuhi kriteria ketuntasan klasikal seperti yang telah ditetapkan dalam penelitian ini yaitu $80 \%$ siswa mencapai nilai $\geq 70$, sehingga masih perlu ditingkatkan dengan mengadakan siklus II.

Hasil evaluasi pada siklus II terdapat 24 orang $(82,76 \%)$ siswa sudah memenuhi target dan 5 orang masih belum memenuhi target yaitu KKM 70. Berdasarkan hasil evaluasi, nilai tertinngi yang diperoleh pada siklus I yaitu 100 sebanyak 5 orang dan nilai terendah 50 sebanyak 2 orang dengan nilai rata-rata kelas 79,31. Hasil evaluasi pada siklus II menunjukkan bahwa ketuntasan belajar siswa secara klasikal mengenai sifat-sifat bangun datar mencapai $82,76 \%$ dengan katagorikan sangat baik. Sehingga penilaian telah memenuhi kriteria ketuntasan klasikal yang telah ditentukan yaitu $80 \%$ siswa memenuhi KKM.

Setelah melakukan perbaikan pada siklus II dari beberapa kekurangan yang terdapat pada siklus I, terjadi perubahan-perubahan ke arah yang lebih baik dan memuaskan, baik dalam proses pembelajarannya maupun dari hasil evaluasi soal latihan matematika siswa, hal ini dapat dibuktikan dengan terjadinya peningkatan skor terhadap aktivitas siswa dan aktivitas guru serta meningkatnya hasil evaluasi soal latihan matematika siswa.

Belum tercapainya ketuntasan klasikal sesuai kriteria ketuntasan yang telah ditetapkan dalam penelitian pada hasil pelaksanaan siklus I tidak terlepas dari beberapa faktor. Faktor yang mempengaruhi yaitu faktor dari siswa kurang memperhatikan penjelasan guru tentang sifat-sifat bangun datar. Kurangnya pemahaman siswa karena enggan atau malu untuk bertanya pada guru hal-hal yang belum dipahami. Konsentrasi siswa sering terganggu karena ada siswa yang yang bermain didalam kelas dan mengganggu temannya. Tidak hanya faktor siswa saja, guru juga kurang tegas dalam mengontrol dan menindak siswa yang bermain di dalam kelas sehingga mempengaruhi proses pembelajaran.

Pada siklus II, jumlah skor aktivitas belajar siswa dan nilai belajar siswa mengalami peningkatan, jumlah presentase aktivitas belajar siswa yang diperoleh adalah $87,5 \%$ yang digolongkan dalam katagori sangat baik, sedangkan rata-rata hasil belajar siswa yang diperoleh adalah 79,31 dengan ketuntasan klasikal yaitu 82,76\%. 
Peningkatan ini terjadi karena pada saat pembelajaran dan latihan berlangsung, sebagian besar siswa memperhatikan apa yang dijelaskan oleh guru, contoh-contoh yang diberikan oleh guru dan mengerjakan latihan dengan sungguh-sungguh.

Peningkatan skor untuk aktivitas siswa dari $75 \%$ pada siklus I menunjukkan peningkatan 12,5 poin menjadi $87,5 \%$ pada siklus II, untuk skor aktivitas guru dari $78,57 \%$ pada siklus I menunjukkan peningkatan 7,14 poin menjadi $85,71 \%$ pada siklus II, dan ketuntasan klasikal hasil evaluasi soal latihan matematika siswa dari 78,57\% pada siklus I menunjukkan peningkatan 4,19 poin menjadi $82,76 \%$ pada siklus II.Dan nilai rata-rata siswa dari 70 menunjukkan peningkatan 9,31 poin menjadi 79,31. Pencapaian skor aktivitas siswa dan aktivitas guru serta hasil evaluasi soal latihan matematika siswa pada siklus II ini telah mencapai kriteria keberhasilan penelitian yang telah ditetapkan.

Berdasarkan uraian di atas dapat kita ketahui bahwa peningkatan hasil belajar matematika dengan penggunaan media gambar dapat meningkatkan aktivitas dan hasil belajar matematika siswa. Media gambar mudah dimengerti dan memudahkan siswa untuk memahami ide-ide abstrak, dengan media gambar mempermudah siswa untuk memahami apa yang dipelajari. Akhirnya, hasil belajar siswa dapat ditingkatkan menjadi lebih baik sehingga minimal dapat sesuai dengan target standar yang telah ditentukan oleh peneliti.

\section{Kesimpulan}

Berdasarkan hasil penelitian ini, dapat ditarik kesimpulan bahwa: 1) Penggunaan media gambar dapat meningkatkan hasi belajar matematika siswa kelas III SDN 1 Midang tahun pelajaran 2014/2015.Peningkatan tersebut ditunjukkan oleh nilai rata-rata hasil belajar siswa dari siklus I ke siklus II. Berdasarkan hasil analisis data dapat diperoleh nilai rata-rata siswa yang awalnya 70 menjadi 78,93. Demikian juga dengan ketuntasan klasikal matematika siswa dari $78,5 \%$ menjadi $82,14 \%$ sehingga penelitian sudah dapat dikatakan berhasil karena telah mencapai ketuntasan yang diharapkan. 2) Penggunaan media gambar dapat meningkatkan keaktifan siswa dalam proses belajar mengajar.Peningkatan tersebut ditunjukkan oleh rata-rata aktivitas siswa yang sebelumnya $75 \%$ dengan katagori aktif menjadi $87,5 \%$ dengan katagori sangat aktif.

\section{Daftar Pustaka}

Arikunto, S. 2010. Prosedur Penelitian Suatu Pendekatan Praktik. Jakarta: PT Bumi Aksara.

Hidayat, K. 2001. Active Learning. Yogyakarta: Yappendis

Mulyono, A. 2003. Pendidikan bagi Anak Berkesulitan Belajar. Jakarta: Rineka Cipta

Rahmawati. 2014. Penggunaan Media Gambar Untuk Meningkatkan Hasil Belajar Matematika Tema Diri Sendiri Pada Siswa Kelas I Sdn Ketemasdungus Mojokerto. JPGSD. 2(3). Pp. 1-6. 